\title{
Vegetation and seed bank of an open-scrub bush restinga formation in the Southeastern coast of Brazil
}

\author{
Fernando Campanhã Bechara ${ }^{1}$, Lívia Zocatelli Salvador ${ }^{2}$, Raquel Almeida Ventura ${ }^{3}$,
} Larissa Regina Topanotti ${ }^{4 *}$, Dionatan Gerber ${ }^{5}$, Izaclaudia Santana da Cruz ${ }^{6} \&$ Marcelo Simonelli $^{7}$

1. Universidade Tecnológica Federal do Paraná, Curso de Engenharia Florestal, Dois Vizinhos, Paraná, Brasil, University of Hawaii at Manoa; bechara@uftpr.edu.br

2. Faculdade de Saúde e Meio Ambiente (FAESA), Vitória, Espírito Santo, Brasil; lzsalvador@hotmail.com

3. Faculdade de Saúde e Meio Ambiente (FAESA), Vitória, Espírito Santo, Brasil; raquelventura@hotmail.com

4. Universidade Federal de Santa Catarina, Divisão de Atividades Agropecuárias, Curitibanos, Santa Catarina, Brasil; larissa.topanotti@ufsc.br

5. Instituto Politécnico de Bragança, Programa de Pós-Graduação em Gestão de Recursos Florestais, Bragança, Bragança, Portugal; dionatan_gerber@hotmail.com

6. Instituto Federal de Educação, Ciência e Tecnologia Baiano, Valença, Bahia, Brasil; izaclaudiasantana@yahoo.com.br

7. Instituto Federal de Educação, Ciência e Tecnologia do Espírito Santo, Vitória, Espírito Santo, Brasil; marcelosimonelli@hotmail.com

* Correspondence

\section{Received 08-X-2019. Corrected 10-I-2020. Accepted 13-III-2020.}

\begin{abstract}
Introduction: Restingas are coastal plain ecosystems located along Eastern Brazil, corresponding to about $5000 \mathrm{~km}$. The restinga vegetation is associated with the Atlantic rainforest biome and comprises four distinct main formation zones: coastal grasslands, shrublands, open-forests and marsh zones. Especially due to coastal urbanization, this is a threatened ecosystem that, through its different shrub formations, exhibits a unique mosaic as a result of the vegetation distribution in nuclei of different covering, physiognomy and floristic composition. Objective: We aimed to characterize the above and belowground composition of a conserved, non-flooded, open-scrub, nuclei (patches of bushes) formation of restinga in Linhares, ES, southeastern Brazil. Methods: The vegetation survey was conducted using the line intercept method. Diameter and height of the first six nuclei were measured in five transects separated by $50 \mathrm{~m}$, totaling 30 nuclei up to $350 \mathrm{~m}$ away from the shore line. The phytosociology and Shannon Index of the aboveground vegetation community were calculated. In the same 30 nuclei, leaf litter and topsoil layer $(15 \times 15 \times 10 \mathrm{~cm})$ samples were collected to survey the viable seed bank, which was later placed in a greenhouse for germination and seedling identification. The Sørensen Similarity index (SSi) was used to compare the floristic composition between the leaf litter and topsoil layer seed banks. Nuclei volume and number of species were calculated as well. Results: In the aboveground vegetation, 54 plant species belonging to 32 families were identified, totaling 1098 individuals. The nuclei showed a diversity ( $\left.\mathrm{H}^{\prime}\right)$ of 3.08 nats, and an average diameter of $11.5 \mathrm{~m}(\mathrm{~s}=9.1)$, area of $526.4 \mathrm{~m}^{2}(\mathrm{~s}=1081.7)$, and height of $2.9 \mathrm{~m}(\mathrm{~s}=1.1)$. Davilla flexuosa, followed by Smilax rufescens, presented the highest IVI (Importance Value Index). A total of 1839 seedlings from 32 species and 19 families were identified in the seed bank. Enydra sessilis (Asteraceae) had the highest seed density (544), while the family with highest species richness was Cyperaceae. A low similarity between the vegetation surveyed and the seed bank composition was found (only
\end{abstract}

Campanhã Bechara, F., Zocatelli Salvador, L., Almeida Ventura, R., Regina Topanotti, L., Gerber, D., Santana da Cruz I., \& Simonelli, M. (2020). Vegetation and seed bank of an open-scrub bush restinga formation in the Southeastern coast of Brazil.. Revista de Biología Tropical, 68(2), 541-550. 
5 species in common, $\mathrm{SSi}=0.10)$. Conclusions: The results indicate that a post-disturbance early community, established from the seed bank, would have a substantially different species composition, but with other potential species to restore vegetation over the long-term succession.

Key words: shrublands, phytosociology, topsoil, nucleation, ecological restoration.

Restingas are coastal plain ecosystems located along Eastern Brazil, from latitude $4^{\circ}$ $\mathrm{N}$ to $34^{\circ} \mathrm{S}$, corresponding to about $5000 \mathrm{~km}$ of the Atlantic coast. The largest restinga systems occur in the State of Rio Grande do Sul and deltas of the major rivers of the Brazilian Southeast and Northeast regions. The soil is composed by sediments classified as marine quartz sands deposited in the Quaternary period, so its origin is related to sedimentary geological phenomena and tidal regime of each location (Lacerda, Araujo, \& Maciel, 1993).

The restinga vegetation is associated with the Atlantic rainforest biome and comprises four distinct main formation zones: coastal grasslands, shrublands, open-forests and marsh zones (Silva, Izeckson, \& Silva, 2000). Since these shrublands patches are, generally, formed by dense bush islets of different sizes, widely spaced by open areas, we prefer to call them "nuclei open-scrub formation", according to the nucleation theory by Yarranton and Morrison (1974).

Especially due to coastal urbanization, this is a threatened ecosystem that, through its different shrub formations, exhibits a unique mosaic, as a result of the distribution of vegetation in nuclei of different covering, physiognomy and floristic composition (Menezes, Souza, \& Castro, 2007; Monteiro, Giaretta, Pereira, \& Menezes, 2014). As an aggravating factor, the knowledge about the regeneration dynamics of this ecosystem is limited, and there is a lack of information about the restinga seed banks.

Seed banks, dormant, viable seeds that are present on the litter or into the soil of a given area, are related to four levels of the regeneration process: population settlement and colonization, species diversity maintenance, ecologic groups and the species richness (Uhl, Clark, Dezzeo, \& Maquirino, 1988; Baker, 1989; Garwood, 1989; Grombone-Guaratini \& Rodrigues, 2002). This paper aimed to characterize the environmental resilience of a non-flooded open-scrub bush restinga formation, through vegetation, leaf litter and seed bank characterization, to better understand its dynamics.

\section{MATERIAL AND METHODS}

Study area: The study site is in the municipality of Linhares, Espírito Santo, (19³9'26.125”' S, 39॰51'19.739”'W), Brazil (Fig. 1). In this region, there are restinga strips of more than $30 \mathrm{~km}$ wide interspersed by extensive open areas (Colodete \& Pereira, 2007). The climate is Aw type according to Köeppen: tropical hot, with moist summers (Oct-Jan; 166 $\mathrm{mm}$ on average) and dry winters (water deficit from Feb-Sep), reaching $1200 \mathrm{~mm}$ per year. The average temperature is 20.7 to $26.2^{\circ} \mathrm{C}$, with the coldest temperatures $\left(20.7^{\circ} \mathrm{C}\right)$ in June and the warmest $\left(26.2^{\circ} \mathrm{C}\right)$ in January.

Vegetation survey: In March 2007, a perpendicular transect $150 \mathrm{~m}$ away from the shoreline towards the interior of the openscrub was established. After this first transect, five transects were positioned, parallel to the shoreline and separated by $50 \mathrm{~m}$ from each other. The first six bush nuclei of each transect were sampled, totaling 30 nuclei, and they were mapped as well (Fig. 1). A bush nucleus was defined as one with a diameter equal or greater than $3 \mathrm{~m}$ and separated from others by a distance of at least $0.5 \mathrm{~m}$ of bare soil. The 


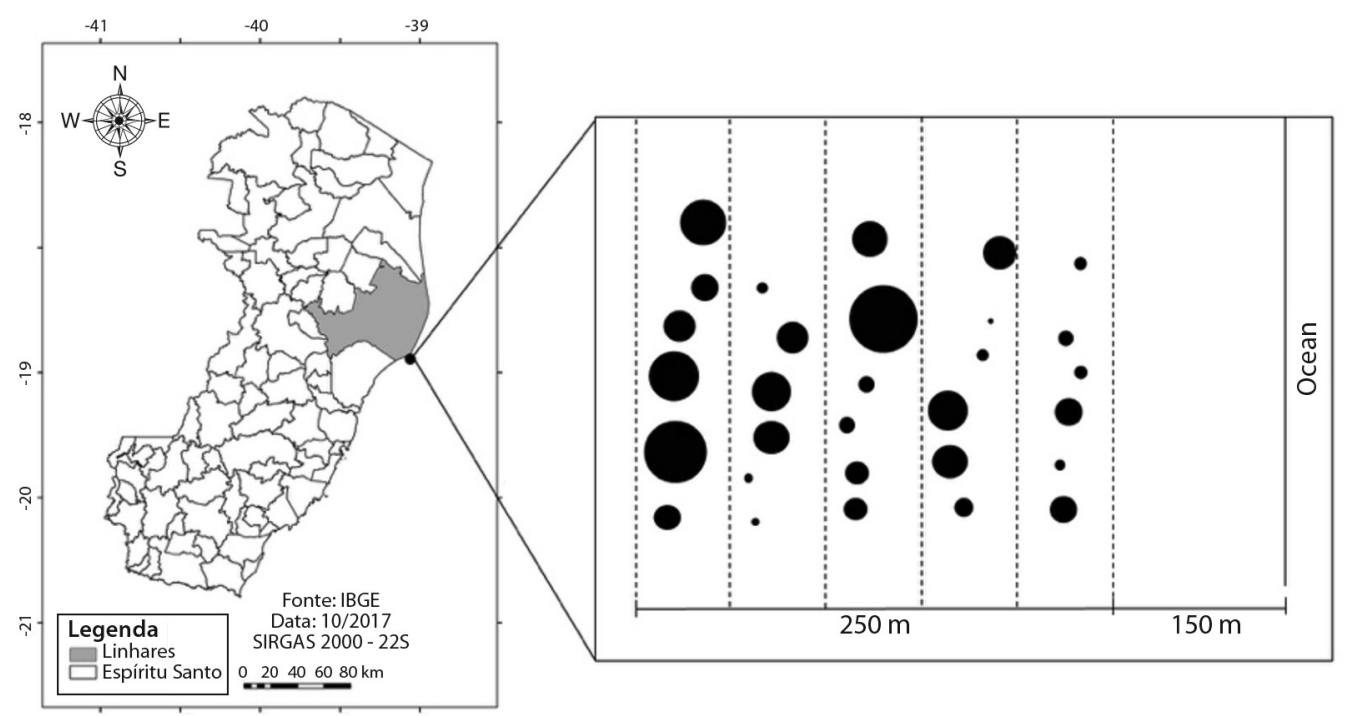

Fig. 1. Distribution of the bush nuclei sampled in an open-scrub restinga formation, non-flooded area, in Linhares (in gray), ES, Brazil.

height and the largest and smallest diameter extensions of all nuclei sampled were registered in order to obtain their volume. Nuclei diameters were measured at $1.0 \mathrm{~m}$ of height. The vegetation survey was conducted using the line intercept method (Müller-Dombois \& Ellenberg, 1974), where all the intercepted plants were identified. The species were identified in the field or by comparison with the herbaria VIES and MBML.

Seed bank: The seed bank was sampled in the same 30 shrub nuclei defined in the vegetation survey (Fig. 1). The soil samples were obtained using a $15 \times 15 \times 10 \mathrm{~cm}$ depth frame. In each nucleus, four random units were sampled, two collected from the litter layer and two from the soil right below the litter. Litter samples (after filtering in a mesh size 6) and topsoil samples were placed into germination trays $(0.61 \times 0.43 \times 0.10 \mathrm{~m})$ with inert nursery substrate, and irrigation in a nursery (shade net covering) near the site. Additionally, control trays were assembled next to each sample tray to certify no contamination by surrounding anemochoric plant species. The composition of the seed bank was estimated using the seedling emergence method in incubated soil, which detects only the fraction of viable seeds (Brown, 1992). The observations were made every 15 days, identifying and quantifying all emergent seedlings. After emergence of the cotyledon leaves, the seedlings were removed from the trays and cultivated in plastic bags with soil, to identify them. Every 15 days, the substrate or topsoil remnant within the trays were mixed to ensure that as many viable seeds as possible would come to the surface and germinate. This procedure lasted for 12 months. Seedlings were identified and counted.

Data analysis: Phytosociology parameters -linear density, frequency and the Importance Value index of each species (Mueller-Dombois \& Ellenberg, 1974)- and the Shannon-Weaver index of diversity for aboveground vegetation were calculated. The Sørensen Similarity index was used to compare the floristic composition between litter and topsoil seed bank, as well as between both and the aboveground vegetation survey. In addition, the regression between the nuclei volume and the number of species was 
calculated $(\alpha=0.05)$ as well its determination coefficient $\left(\mathrm{R}^{2}\right)$ value.

\section{RESULTS}

Vegetation survey: The aboveground vegetation was composed by 54 species from 32 families. The families with higher species richness were Bromeliaceae (6 spp.), Orchidaceae (5), Myrtaceae (4), and Erythroxylaceae (3). We sampled a total of 1098 individuals in 430 linear meters. Most of the species found in the aboveground were herbs (40.7\%), followed by shrubs and trees, representing $27.8 \%$ each, and lianas (3.7\%). Davilla flexuosa, Smilax rufescens, Guapira pernambucensis, Allagoptera arenaria and Paullinia weinmanniaefolia presented the highest Importance Values (Table 1).

Three of the identified species are listed in the red book of species of Espírito Santo flora threatened by extinction (Simonelli \& Fraga,

TABLE 1

Phytosociology in an open-scrub bush restinga formation in Linhares, ES, Brazil

\begin{tabular}{|c|c|c|c|c|c|c|c|c|c|}
\hline Family & Species & $\mathrm{N}$ & $\mathrm{COV}$ & $\mathrm{AD}$ & $\mathrm{RD}$ & $\mathrm{AF}$ & RF & IV & LF \\
\hline Dilleniaceae & Davilla flexuosa & 177 & 183 & 0.412 & 69.191 & 0.426 & 0.119 & 69.310 & S \\
\hline Smilacaceae & Smilax rufescens & 153 & 156 & 0.356 & 59.809 & 0.363 & 0.102 & 59.911 & $\mathrm{~L}$ \\
\hline Nyctaginaceae & Guapira pernambucensis & 63 & 79 & 0.147 & 24.627 & 0.184 & 0.052 & 24.679 & $\mathrm{~T}$ \\
\hline Arecaceae & Allagoptera arenaria & 62 & 143 & 0.144 & 24.236 & 0.333 & 0.093 & 24.330 & $\mathrm{H}$ \\
\hline Sapindaceae & Paullinia weinmanniaefolia & 60 & 60 & 0.14 & 23.455 & 0.140 & 0.039 & 23.494 & $\mathrm{~S}$ \\
\hline Araceae & Anthurium raimundii & 59 & 61 & 0.137 & 23.064 & 0.142 & 0.040 & 23.103 & $\mathrm{H}$ \\
\hline Polygonaceae & Coccoloba alnifolia & 50 & 129 & 0.116 & 19.545 & 0.300 & 0.084 & 19.630 & $\mathrm{~S}$ \\
\hline Peraceae & Pera glabrata & 50 & 127 & 0.116 & 19.545 & 0.295 & 0.083 & 19.628 & $\mathrm{~S}$ \\
\hline Bromeliaceae & Aechmea nudicaulis & 48 & 55 & 0.112 & 18.764 & 0.128 & 0.036 & 18.800 & $\mathrm{H}$ \\
\hline Poaceae & Axonopus pressus & 47 & 47 & 0.109 & 18.373 & 0.109 & 0.031 & 18.403 & $\mathrm{H}$ \\
\hline Burseraceae & Protium heptaphyllum & 41 & 92 & 0.095 & 16.027 & 0.214 & 0.06 & 16.087 & $\mathrm{~T}$ \\
\hline Malpighiaceae & Byrsonima sericea & 41 & 24 & 0.095 & 16.027 & 0.056 & 0.016 & 16.043 & $\mathrm{~T}$ \\
\hline Bromeliaceae & Vriesea procera & 25 & 26 & 0.058 & 9.773 & 0.060 & 0.017 & 9.790 & $\mathrm{H}$ \\
\hline Clusiaceae & Clusia hilariana & 23 & 66 & 0.053 & 8.991 & 0.153 & 0.043 & 9.034 & S \\
\hline Chrysobalanaceae & Chrysobalanus icaco & 22 & 42 & 0.051 & 8.600 & 0.098 & 0.027 & 8.627 & S \\
\hline Sapindaceae & Cupania emarginata & 19 & 28 & 0.044 & 7.427 & 0.065 & 0.018 & 7.446 & $\mathrm{~T}$ \\
\hline Primulaceae & Myrsine umbellata & 14 & 22 & 0.033 & 5.473 & 0.051 & 0.014 & 5.487 & $\mathrm{~T}$ \\
\hline Rubiaceae & Salzmannia nitida & 14 & 18 & 0.033 & 5.473 & 0.042 & 0.012 & 5.484 & S \\
\hline Sapotaceae & Manilkara subsericea & 12 & 18 & 0.028 & 4.691 & 0.042 & 0.012 & 4.703 & S \\
\hline Primulaceae & Myrsine parvifolia & 11 & 12 & 0.026 & 4.300 & 0.028 & 0.008 & 4.308 & $\mathrm{~T}$ \\
\hline Fabaceae & Swartzia apetala & 10 & 11 & 0.023 & 3.909 & 0.026 & 0.007 & 3.916 & $\mathrm{~T}$ \\
\hline Cactaceae & Pilosocereus arrabidae & 9 & 12 & 0.021 & 3.518 & 0.028 & 0.008 & 3.526 & $\mathrm{H}$ \\
\hline Orchidaceae & Vanilla bahiana & 9 & 10 & 0.021 & 3.518 & 0.023 & 0.007 & 3.525 & $\mathrm{H}$ \\
\hline Fabaceae & Abarema jupunba & 7 & 15 & 0.016 & 2.736 & 0.035 & 0.010 & 2.746 & $\mathrm{~T}$ \\
\hline Erythroxylaceae & Erythroxylum sp. (1) & 7 & 9 & 0.016 & 2.736 & 0.021 & 0.006 & 2.742 & $\mathrm{~S}$ \\
\hline Anacardiaceae & Schinus terebinthifolius & 5 & 7 & 0.012 & 1.955 & 0.016 & 0.005 & 1.959 & $\mathrm{~T}$ \\
\hline Bromeliaceae & Bromeliaceae sp. & 5 & 5 & 0.012 & 1.955 & 0.012 & 0.003 & 1.958 & $\mathrm{H}$ \\
\hline Asteraceae & Mikania glomerata & 5 & 5 & 0.012 & 1.955 & 0.012 & 0.003 & 1.958 & $\mathrm{H}$ \\
\hline Bromeliaceae & Vriesea neoglutinosa & 5 & 5 & 0.012 & 1.955 & 0.012 & 0.003 & 1.958 & $\mathrm{H}$ \\
\hline Myrtaceae & Eugenia rotundifolia & 4 & 7 & 0.009 & 1.564 & 0.016 & 0.005 & 1.568 & $\mathrm{~T}$ \\
\hline Lauraceae & Ocotea notata & 4 & 5 & 0.009 & 1.564 & 0.012 & 0.003 & 1.567 & $\mathrm{~T}$ \\
\hline Cactaceae & Cereus fernambucensis & 4 & 4 & 0.009 & 1.564 & 0.009 & 0.003 & 1.566 & $\mathrm{H}$ \\
\hline Apocynaceae & Oxypetalum banksii & 4 & 4 & 0.009 & 1.564 & 0.009 & 0.003 & 1.566 & $\mathrm{H}$ \\
\hline
\end{tabular}




\begin{tabular}{|c|c|c|c|c|c|c|c|c|c|}
\hline Family & Species & $\mathrm{N}$ & $\mathrm{COV}$ & $\mathrm{AD}$ & $\mathrm{RD}$ & $\mathrm{AF}$ & $\mathrm{RF}$ & IV & LF \\
\hline Calophyllaceae & Kielmeyera albopunctata & 3 & 4 & 0.007 & 1.173 & 0.009 & 0.003 & 1.175 & $\mathrm{~S}$ \\
\hline Orchidaceae & Catasetum discolor & 2 & 3 & 0.005 & 0.782 & 0.007 & 0.002 & 0.784 & $\mathrm{H}$ \\
\hline Myrtaceae & Eugenia sp. & 2 & 4 & 0.005 & 0.782 & 0.009 & 0.003 & 0.784 & $\mathrm{~T}$ \\
\hline Euphorbiaceae & Sebastiania glandulosa & 2 & 3 & 0.005 & 0.782 & 0.007 & 0.002 & 0.784 & $\mathrm{~S}$ \\
\hline Orchidaceae & Tillandsia stricta & 2 & 3 & 0.005 & 0.782 & 0.007 & 0.002 & 0.784 & $\mathrm{H}$ \\
\hline Erythroxylaceae & Erythroxylum sp. (3) & 2 & 2 & 0.005 & 0.782 & 0.005 & 0.001 & 0.783 & $\mathrm{~S}$ \\
\hline Bromeliaceae & Quesnelia quesneliana & 2 & 2 & 0.005 & 0.782 & 0.005 & 0.001 & 0.783 & $\mathrm{H}$ \\
\hline Bromeliaceae & Aechmea blanchetiana & 1 & 4 & 0.002 & 0.391 & 0.009 & 0.003 & 0.394 & $\mathrm{H}$ \\
\hline Polygonaceae & Coccoloba arborescens & 1 & 3 & 0.002 & 0.391 & 0.007 & 0.002 & 0.393 & $\mathrm{~S}$ \\
\hline Bignoniaceae & Arrabidaea conjugata & 1 & 1 & 0.002 & 0.391 & 0.002 & 0.001 & 0.392 & $\mathrm{H}$ \\
\hline Rubiaceae & Borreria verticillata & 1 & 1 & 0.002 & 0.391 & 0.002 & 0.001 & 0.392 & $\mathrm{H}$ \\
\hline Capparaceae & Capparis flexuosa & 1 & 1 & 0.002 & 0.391 & 0.002 & 0.001 & 0.392 & $\mathrm{H}$ \\
\hline Fabaceae & Chamaecrista flexuosa & 1 & 1 & 0.002 & 0.391 & 0.002 & 0.001 & 0.392 & $\mathrm{~S}$ \\
\hline Orchidaceae & Cyrtopodium polyphyllum & 1 & 2 & 0.002 & 0.391 & 0.005 & 0.001 & 0.392 & $\mathrm{H}$ \\
\hline Erythroxylaceae & Erytthroxylum sp. (2) & 1 & 1 & 0.002 & 0.391 & 0.002 & 0.001 & 0.392 & $\mathrm{~S}$ \\
\hline Orchidaceae & Koellensteinia altissima & 1 & 2 & 0.002 & 0.391 & 0.005 & 0.001 & 0.392 & $\mathrm{H}$ \\
\hline Poaceae & Melinis minutiflora & 1 & 1 & 0.002 & 0.391 & 0.002 & 0.001 & 0.392 & $\mathrm{H}$ \\
\hline Passifloraceae & Passiflora $\mathrm{sp}$. & 1 & 1 & 0.002 & 0.391 & 0.002 & 0.001 & 0.392 & $\mathrm{~L}$ \\
\hline Schoepfiaceae & Schoepfia brasiliensis & 1 & 2 & 0.002 & 0.391 & 0.005 & 0.001 & 0.392 & $\mathrm{~T}$ \\
\hline Myrtaceae & Myrciaria floribunda & 1 & 1 & 0.002 & 0.391 & 0.002 & 0.001 & 0.392 & $\mathrm{~T}$ \\
\hline Myrtaceae & Psidium macahense & 1 & 1 & 0.002 & 0.391 & 0.002 & 0.001 & 0.392 & $\mathrm{~T}$ \\
\hline Total & & 1098 & 1.53 & 2.55 & 429.22 & 3.56 & 1.00 & 430.22 & \\
\hline Mean & & 20.33 & 28.33 & 0.09 & 7949 & 0.06 & 0.019 & 7967 & \\
\hline
\end{tabular}

$\mathrm{N}=$ number of individuals; $\mathrm{COV}=$ coverage $(\mathrm{m}) ; \mathrm{AD}=$ absolute linear density; $\mathrm{RD}=$ relative linear density $(\%) ; \mathrm{AF}=$ absolute frequency $(\%) ; \mathrm{RF}=$ relative frequency $(\%) ; \mathrm{IV}=$ importance value; $\mathrm{LF}=$ life form: $\mathrm{H}=$ herb, $\mathrm{L}=$ liana, $\mathrm{S}=\mathrm{shrub}$, $\mathrm{T}=$ tree.

2007): Axonopus pressus, restricted to the North of the state, is listed as critically endangered, as well as Aechmea blanchetiana and Vriesea neoglutinosa, classified as vulnerable. The most frequent species was Allagoptera arenaria (Arecaceae), which occurred in all lines. Other species, such as Axonopus pressus, G. pernambucensis, S. rufescens, $P$. weinmanniaefolia, Pera glabrata and D. flexuosa, were also highly frequent in more than 20 nuclei. The diversity index of Shannon-Weaver $\left(\mathrm{H}^{\prime}\right)$ was 3.08 nats for the whole experimentation site. The volumes of the studied nuclei varied from $29.3 \mathrm{~m}^{3}$ to $22562.5 \mathrm{~m}^{3}$, with an average diameter of $11.5 \mathrm{~m}$, mean area of $526.4 \mathrm{~m}^{2}$ and mean height of $2.9 \mathrm{~m}$. Most nuclei had a maximum volume of $1000 \mathrm{~m}^{3}$, with richness of 5-17 species each. The largest number of species was observed in the most voluminous nucleus $\left(22562.54 \mathrm{~m}^{3}\right)$, with 31 species sampled. The second richest nucleus, despite having a volume almost eight times smaller than the first, sheltered 30 different species. Therefore, a weak tendency of increasing richness with the increasing of the nucleus size was noted, with a coefficient of termination $\left(\mathrm{R}^{2}\right)$ of 0.487 . The maximum nucleus height was $6 \mathrm{~m}$, particularly represented by Clusia hilariana and Coccoloba alnifolia.

Seed bank: The highest proportion of germinated seeds occurred in the first four months of observation, showing a decrease in the following seven months followed by an increase in the last three months. A total of 1839 seedlings were recorded in the seed bank (litter plus topsoil) distributed in 32 species and 19 families (Table 2). Enydra sessilis presented the highest density (544), followed by Poaceae sp. 2 (371). The most abundant family 
TABLE 2

Seedlings germinated from the seed bank survey in an open-scrub bush restinga formation in Linhares, ES, Southeastern Brazil

\begin{tabular}{|c|c|c|c|c|c|}
\hline Family & Species & $\mathrm{N}$ & Ts & $\mathrm{Li}$ & $\mathrm{LF}$ \\
\hline Asclepiadaceae & Oxypetalum banksii & 2 & & $\mathrm{X}$ & liana \\
\hline \multirow[t]{3}{*}{ Asteraceae } & Enydra sessilis & 544 & $\mathrm{X}$ & $\mathrm{X}$ & herb \\
\hline & Pluchea sagittalis & 139 & $\mathrm{X}$ & $\mathrm{X}$ & herb \\
\hline & Vernonia scorpioides & 1 & $\mathrm{X}$ & & shrub \\
\hline Blechnaceae & Telmatoblechnum serrulatum & 5 & $\mathrm{X}$ & $\mathrm{X}$ & herb \\
\hline Bromeliaceae & Quesnelia quesneliana & 1 & & $\mathrm{X}$ & herb \\
\hline Cactaceae & Pilosocereus arrabidae & 8 & $\mathrm{X}$ & $\mathrm{X}$ & herb \\
\hline Curcubitaceae & sp. 1 & 1 & $\mathrm{X}$ & & indet. \\
\hline \multirow[t]{4}{*}{ Cyperaceae } & Bulbostylis capillaris & 8 & $\mathrm{X}$ & $\mathrm{X}$ & herb \\
\hline & Cyperus haspan & 1 & $\mathrm{X}$ & & herb \\
\hline & Cyperus ligularis & 138 & $\mathrm{X}$ & $\mathrm{X}$ & herb \\
\hline & Fimbristylis aspera & 3 & $\mathrm{X}$ & & herb \\
\hline Erythroxylaceae & Erythroxylum sp. & 10 & $\mathrm{X}$ & $\mathrm{X}$ & tree \\
\hline \multirow[t]{2}{*}{ Euphorbiaceae } & Euphorbia heterophylla & 1 & $\mathrm{X}$ & & herb \\
\hline & Sebastiania glandulosa & 34 & $\mathrm{X}$ & $\mathrm{X}$ & herb \\
\hline Fabaceae & Chamaecrista ramosa & 3 & $\mathrm{X}$ & & herb \\
\hline Melastomataceae & Miconia albicans & 3 & $\mathrm{X}$ & & tree \\
\hline Molluginaceae & Mollugo verticillata & 358 & $\mathrm{X}$ & $\mathrm{X}$ & herb \\
\hline Poaceae & sp. 2 & 371 & $\mathrm{X}$ & $\mathrm{X}$ & herb \\
\hline Portulacaceae & sp. 3 & 28 & $\mathrm{X}$ & $\mathrm{X}$ & herb \\
\hline Primulaceae & Myrsine umbellata & 4 & $\mathrm{X}$ & & tree \\
\hline Pteridaceae & Pityrogramma calomelanos & 76 & $\mathrm{X}$ & $\mathrm{X}$ & herb \\
\hline \multirow[t]{2}{*}{ Rubiaceae } & Borreria verticillata & 2 & $\mathrm{X}$ & & herb \\
\hline & Diodia sp. & 3 & $\mathrm{X}$ & & herb \\
\hline Smilacaceae & Smilax rufescens & 1 & $\mathrm{X}$ & & liana \\
\hline \multirow[t]{2}{*}{ Solanaceae } & Solanum americanum & 4 & $\mathrm{X}$ & $\mathrm{X}$ & shrub \\
\hline & sp. 4 & 5 & $\mathrm{X}$ & $\mathrm{X}$ & indet. \\
\hline \multirow[t]{4}{*}{ Indet. } & sp. 1 & 54 & $\mathrm{X}$ & $\mathrm{X}$ & indet. \\
\hline & sp. 2 & 3 & $\mathrm{X}$ & & indet. \\
\hline & sp. 3 & 16 & $\mathrm{X}$ & & indet. \\
\hline & sp. 4 & 5 & $\mathrm{X}$ & & indet. \\
\hline Urticaceae & Cecropia hololeuca & 7 & $\mathrm{X}$ & & tree \\
\hline Total & & 1839 & & & \\
\hline
\end{tabular}

$\mathrm{N}=$ total of seedlings; $\mathrm{Ts}=$ topsoil layer; $\mathrm{Li}=$ leaf litter; $\mathrm{LF}=$ life form; indet. = indeterminate species.

was Cyperaceae, represented by four species. Most species were herbs (56.25\%), but species of trees $(12.5 \%)$, shrubs $(6.25 \%)$ and lianas $(6.25 \%)$ were also observed.

Among the individuals listed, $64.6 \%$ emerged from topsoil samples and $35.3 \%$ emerged from litter. A number of 15 species were recorded exclusively in the topsoil samples, 2 exclusively in the litter and 15 species were common to both samples (Table 2). The Sørensen Similarity index (0.10) between the species sampled in the aboveground vegetation survey and those emerged from the seed bank (both litter and topsoil combined), showed low similarity $(10 \%)$, indicating that most of the species are not shared between 
both. Only five species were common to both aboveground and seed bank: the herbs Borreria verticillata, Pilosocereus arrabidae, Quesnelia quesneliana, Sebastiania glandulosa and the liana $S$. rufescens.

\section{DISCUSSION}

In the aboveground vegetation, $D$. flexuosa was classified as the most abundant species in our study, and it seems to be a common species in this type of ecosystem. The palm tree $A$. arenaria occurred in all the transects of the sampled area and was included among the three species with the highest Importance Value. Allagoptera arenaria has a wide occurrence in both open-scrub and "closed" restinga formations with the ability to be disseminated by seed or rhizomatous growth and sprouting after burning (Pereira, Cordeiro, \& Araujo, 2004). Protium heptaphyllum was among the ten species with the highest IV, like studies conducted in other restingas (Pereira \& Araujo, 2000). G. pernambucensis is widely distributed throughout tropical South America, according to Araujo, Oliveira, Vieira, Barros and Lima (2001). Both B. sericea and S. terebinthifolius are more common in disturbed areas. In restinga formations, Bromeliaceae is known to be common (as the ones found in our study Aechmea blanchetiana, Aechmea nudicaulis, Q. quesneliana and Vriesea procera) and are fundamental elements in this physiognomy composition, since they play an important ecological role, including the capacity to store water in their tanks and act as sites for germination and development of other plant species, which makes them "focal plants", important in maintaining the diversity of restinga habitats (Scarano, 2002). Melinis minutiflora, an invasive grass of African origin, reproduces both by seeds and vegetatively. It is sensitive to fire, but adapted to the condition of low soil fertility, being present in open and sunny environments. It has invaded large areas of tropical ecosystems, displacing native species due to its aggressiveness and superior competitive capacity. This species occurred in low abundance in our study, but still deserves special attention due to its biological invasive potential. A. pressus occurs in the open formation of Ericaceae restinga and was listed in the Espírito Santo red book as critically endangered, as well as A. blanchetiana and $V$. neoglutinosa, which are listed as vulnerable species (Simonelli \& Fraga, 2007). About rare species, in our study they were represented only by $1.45 \%$ of the total sampled, analogous to the rare species percentage of a restinga in Rio de Janeiro (2 \%) (Pereira et al., 2004), but lower than the rate in another restinga in Espírito Santo (7.1 $\%$ ) (Monteiro et al., 2014). Therefore, the Shannon-Weaner diversity index (H') obtained in our study $(\mathrm{H}=3.08$ nats $)$ was higher than the $\mathrm{H}^{\prime}=2.84$ nats found by Pereira \& Araujo (2000) and $H^{\prime}=1.89$ nats registered in Pereira et al. (2004), both in open restingas, probably because it is a more conserved site than the other studies cited above.

Although the regression's coefficient of determination was low, there was an increase in the number of species in relation to the nuclei volume, and the highest number of species was observed in the most voluminous nuclei. This might be related to the fact that some species might be more abundant under shrubs and others would prefer areas without coverage to develop (Shmida \& Whittaker, 1981). Even though restingas are highly stressful ecosystems in terms of salinity, low fertilization, high radiation, low water availability on soil, wind exposure and sand burial, dense groups of plants facilitate the establishment of new species in these ecosystems due to their improvement in microclimate factors (Shumway, 2000). The nuclei found in this study may act in a nucleation process (Bechara et. al, 2014). These plants may play a key role in plants assemblages, especially in xerophytic environments, since they contribute to the improvement of conditions for germination, establishment and growth of other plant species (Zaluar \& Scarano, 2000). For example, Clusia hilariana, which is often described as a nurseplant, since it presents positive association between adults and juvenile density of other 
woody species and works as dispersers attractive in restingas (Dias, Zaluar, Ganade, \& Scarano, 2005; Correia, Dias, \& Scarano 2010).

The seedlings diversity from seed bank in our study is like other studies in restingas. Cyperaceae, the most abundant family, and Cyperus spp., are frequently found on restingas seed banks. Asteraceae, the second most abundant family, was also one of the most significant families in the floristic composition of Santa Catarina's restingas (Klein, Citadini-Zanette \& Santos, 2007; Korte, de Gasper, Kruger, \& Sevegnani, 2013). The most abundant species, E. sessilis, occurs in aquatic and terrestrial sites in restingas, so it can be considered an amphibian species. Poaceae, as the second family with more individuals, also occur in other restingas sites. The third most abundant species, $M$. verticillata, is one of the ten most abundant species as well in a restinga in Rio de Janeiro (Pereira et al., 2004). The predominance of herbs in the seed bank and in the aboveground vegetation is typical in restingas, and they are important especially in terms of soil coverage, interaction with other life form species and early ecological succession.

Regarding the germination over time, it is commonly reported that seed banks have rapid germination response in the first months of studies. Costa and Araújo (2003) reported the highest proportion of germinated seeds in the first month of observation. Caldato, Floss, Croce and Longhi (1996) also found that most of the seedlings emerged in the first four months, as in our study. Nonetheless, it is important to highlight that the soil seed bank of open areas such as restingas is mainly composed of species that germinate under constant sunlight. Most of the taxa emerged from seed bank in our study follow a pioneer species behavior, which is common in restingas, where the successional groups form mosaics defined by the diversity of different levels of soil-dependent climax. The richness of this seed bank (33 spp.) is like the results obtained by Bechara and Reis (2009), where the authors found a diversity of 35 species in a restinga site in Santa Catarina.
The low similarity between the aboveground vegetation floristic composition and the sampled seed bank indicates that early communities, after disturbances, could be significantly different in these delicate ecosystems. The higher diversity in the aboveground vegetation indicates a more mature community. The high abundance of seedlings found in seed banks indicates that they may be used as an important low-cost tool for open-scrub restinga restoration in nuclei (see Bechara et al., 2016).

Ethical statement: authors declare that they all agree with this publication and made significant contributions; that there is no conflict of interest of any kind; and that we followed all pertinent ethical and legal procedures and requirements. All financial sources are fully and clearly stated in the acknowledgements section. A signed document has been filed in the journal archives.

\section{RESUMEN}

Vegetación y banco de semillas en una formación de matorral abierto de restinga en el sureste de Brasil. Introducción: Las restingas son ecosistemas llanos costeros ubicados a lo largo del este de Brasil, que corresponden a unos $5000 \mathrm{~km}$ de la costa atlántica brasileña. La vegetación de restinga está asociada con el bioma de la selva tropical atlántica y comprende cuatro zonas de formación principales: praderas costeras, matorrales, bosques abiertos y zonas pantanosas. Especialmente debido a la urbanización costera, este es un ecosistema amenazado, que, a través de sus formaciones arbustivas, exhibe un mosaico único, como resultado de la distribución de la vegetación en núcleos de diferentes coberturas, fisonomía y composición florística. Objetivo: Caracterizar la composición florística superficial y subterránea de una formación conservada, no inundada, de núcleos de matorral abierto de restinga en Linhares, ES, costa del sureste de Brasil. Métodos: La vegetación se muestreó utilizando el método de la línea de intercepción. El diámetro y la altura de los primeros seis núcleos se midieron en cinco transectos instalados cada $50 \mathrm{~m}$, con un total de 30 núcleos distantes hasta 350 $\mathrm{m}$ de la línea de costa. Se muestreó la comunidad de vegetación y se calculó su fitosociología e índice de Shannon. En los mismos 30 núcleos, se recogió la hojarasca más la capa superior del suelo $(15 \times 15 \times 10 \mathrm{~cm})$ para examinar el banco de semillas viable, que luego se colocó en un invernadero para germinar e identificar las plántulas. El índice de similitud de Sørensen se usó para comparar la composición florística entre la hojarasca y el banco de semillas de 
la capa superficial del suelo y también se calculó la regresión entre el volumen del núcleo y el número de especies. Resultados: En la vegetación superficial se identificaron 54 especies de plantas pertenecientes a 32 familias, con un total de 1098 plantas. Los núcleos registraron una diversidad (H') de 3.08 nats, y un diámetro promedio de $11.5 \mathrm{~m}$ (s =9.1), área de $526.4 \mathrm{~m}^{2}(\mathrm{~s}=1081.7)$ y altura de $2.9 \mathrm{~m}(\mathrm{~s}=$ 1.1). Davilla flexuosa, seguida de Smilax rufescens, presentó el VI (Valor de Importancia) más alto. Se identificaron un total de 1839 plántulas de 32 especies y 19 familias en el banco de semillas. Enydra sessilis (Asteraceae) tuvo la mayor densidad de semillas viables (544), pero la familia con mayor riqueza de especies fue Cyperaceae. Se encontró una baja similitud entre la vegetación y la composición del banco de semillas (solo 5 especies en común, índice de Sørensen $=0.10)$. Conclusiones: Los resultados indican que una comunidad recién establecida después de una alteración podría tener una composición de especies sustancialmente diferente, pero con otras especies potenciales para restaurar la vegetación a largo plazo.

Palabras clave: matorrales, fitosociología, capa superficial del suelo, nucleación, restauración ecológica.

\section{REFERENCES}

Araujo, M.M., Oliveira, F.A., Vieira, I.C.G., Barros, P.L.C., \& Lima, C.A.T. (2001). Densidade e composição florística do banco de sementes do solo de florestas sucessionais na região do Baixo Rio Guamá, Amazônia Oriental. Scientia Forestalis, 59, 115-130.

Baker, H.G. (1989). Some Aspects of the Natural History of Seed Banks. In M.A. Leck, T.V. Parker, \& R.L. Simpson (Eds.), Ecology of Soil Seed Banks (pp. 9-21). New York, NY: Academic Press.

Bechara, F.C., \& Reis, A. (2009). Banco de sementes no Parque Florestal do Rio Vermelho. In D.R. Tres \& A. Reis (Eds.), Perspectivas sistêmicas para a conservação e restauração ambiental: do pontual ao contexto (pp. 1-374). Itajaí, SC, Brazil: Herbário Barbosa Rodrigues.

Bechara, F.C., Dickens, S.J., Farrer, E.C., Larios, L., Spotswood, E.N., Mariotte, P., \& Suding, K.N. (2016). Neotropical rainforest restoration: comparing passive, plantation and nucleation approaches. Biodiversity and Conservation, 25, 2021-2034.

Brown, B. (1992). Estimating the composition of a forest seed bank: a comparison of the seed extraction and seedling emergence methods. Canadian Journal of Botany, 70(8), 1603-1612.

Caldato, S.L., Floss, P.A., Croce, D.M., \& Longhi, S.J. (1996). Estudo da regeneração natural, banco de sementes e chuva de sementes na Reserva Genética Florestal de Caçador, SC. Ciência Florestal, 6(1), 27-38.
Colodete, M.F., \& Pereira, O.J. (2007). Levantamento florístico da Restinga de Regência, Linhares, ES. Revista Brasileira de Biociências, 5, 558-560.

Correia, C.M.B., Dias, A.T.C., \& Scarano, F.R. (2010). Plant-plant associations and population structure of four woody plant species in a patchy coastal vegetation of Southeastern Brazil. Revista Brasileira de Botânica, 33(4), 607-613.

Costa, R.C., \& Araújo, F.S. (2003). Densidade, germinação e flora do banco de sementes no solo, no final da estação seca, em uma área de caatinga, Quixadá, CE. Acta Botanica Brasilica, 17(2), 259-264.

Dias, A.T.C., Zaluar, H.L.T., Ganade, G., \& Scarano, F.R. (2005). Canopy composition influencing plant patch dynamics in a Brazilian sandy coastal plain. Journal of Tropical Ecology, 21(3), 343-347.

Garwood, N.C. (1989). Tropical soil seed banks: a review. In M.A. Leck, T.V. Parker, \& R.L. Simpson (Eds.), Ecology of Soil Seed Banks (pp. 149-209). New York, NY: Academic Press.

Grombone-Guaratini, M.T., \& Rodrigues, R.R. (2002). Seed bank and seed rain in a seasonal semi-deciduous forest in Southeastern Brazil. Journal of Tropical Ecology, 18, 759-774.

Klein, A.S., Citadini-Zanette, V., \& Santos, R. (2007). Florística e estrutura comunitária de Restinga herbácea no município de Araranguá, Santa Catarina. Biotemas, 20(3), 15-36.

Korte, A., de Gasper, A.L., Kruger, A., \& Sevegnani, L. (2013). Composição florística e estrutura das Restingas em Santa Catarina. In A.C. Vibrans, L. Sevegnani, A.L. de Gasper, \& D.V. Lingner (Eds.), Inventário Florístico Florestal de Santa Catarina (pp. 285-309). Blumenau: Edifurb.

Lacerda, L.D., Araujo, D.S.D., \& Maciel, N.C. (1993). Dry coastal ecosystems of the tropical Brazilian coast. In E. van der Maarel (Ed.), Dry coastal ecosystems: Africa, America, Asia, Oceania (pp. 477-493). Amsterdam: Elsevier.

Menezes, L.F.T., Souza, M., \& Castro, D.N. (2007). Estrutura da formação arbustiva aberta não-inundável na Restinga da Marambaia (RJ). Revista Brasileira de Biociencias, 5, 75-77.

Monteiro, M.M., Giaretta, A., Pereira, O.J., \& Menezes, L.F.T. (2014). Composição e estrutura de uma Restinga arbustiva aberta no norte do Espírito Santo e relações florísticas com formações similares no Sudeste do Brasil. Rodriguésia, 65(1), 61-72.

Müller-Dombois, D., \& Ellenberg, H. (1974). Aims and methods of vegetation ecology. New York, NY: JohnWiley \& Sons. 
Pereira, M.C.A., Cordeiro, S.Z., \& Araujo, D.S.D. (2004) Estrutura do estrato herbáceo na formação aberta de Clusia do Parque Nacional da Restinga de Jurubatiba, RJ, Brasil. Acta Botânica Brasílica, 18(3), 677-687.

Pereira, O.J., \& Araújo, D.S.D. (2000). Análise florística das Restingas dos estados do Espírito Santo e Rio de Janeiro. In F.A. Esteves \& I.D. Lacerda (Eds.), Ecologia de Restingas e lagoas costeiras (pp. 25-63). Rio de Janeiro, Brazil: NUPEM/UFRJ.

Scarano, F.R. (2002). Structure, function and floristic relationships of plant communities in stressful habitats marginal to the Brazilian Atlantic rainforest. Annals of Botany, 90(4), 517-524.

Shmida, A., \& Whittaker, R.H. (1981). Pattern and biological microsite effects in two shrub communities, Southern California. Ecology, 62(1), 243-251.

Shumway, S.W. (2000). Facilitative effects of a sand dune shrub on species growing beneath the shrub canopy. Oecologia, 124(1), 138-148.
Silva, S.P.C., Izeckson, E., \& Silva, A.M.P.T.C. (2000). Diversidade e ecologia de anfíbios em Restingas do sudeste brasileiro. In F.A. Esteves \& I.D. Lacerda (Eds.), Ecologia de Restingas e lagoas costeiras (pp. 89-97). Rio de Janeiro, Brazil: NUPEM/UFRJ.

Simonelli, M., \& Fraga, C.N. (2007). Espécies da flora ameaçadas de extinção no estado do Espírito Santo. Vitória: Ipema.

Uhl, C., Clark, K., Dezzeo, N., \& Maquirino, P. (1988). Vegetation dynamics in Amazonian treefall gaps. Ecology, 69(3), 751-763.

Zaluar, H.L.T., \& Scarano, F.R. (2000). Facilitação em Restingas de moitas: um século de buscas por espécies focais. In F.A. Esteves \& I.D. Lacerda (Eds.), Ecologia de Restingas e lagoas costeiras (pp. 3-23). Rio de Janeiro, Brazil: NUPEM/UFRJ.

Yarranton, G.A., \& Morrison, R.G. (1974). Spatial dynamics of a primary succession: nucleation. Journal of Ecology, 62(2), 417-428. 